\title{
KEPERCAYAAN BUBUHAN KUMAI terhadap Tuhan dan Makhluk Halus
}

\author{
Sulaiman Al-Kumayi \\ IAIN Walisongo Semarang
}

\begin{abstract}
One important part of the belief system is a belief which covers trust in God the Almighty and trust regarding the presence of supernatural being. In relation to Bubuhan Kumai, this community has built a system of belief which reflects their understanding and interpretation of Islam religious devotion which they embrace. Islam religion is not immediately able to remove local beliefs deeply rooted in the memory of Bubuhan Kumai communities. This article describes about the belief system of Bubuhan Kumai which covers the belief to the God the Almighty and belief of the presence of the supernatural being, employing experiences of the participants of the culture studied.
\end{abstract}

Key words: belief system, religion, tribal community, central Kalimantan.

\section{Pendahuluan}

Tulisan ini menyajikan tentang masyarakat yang disebut Bubuhan Kumai yang tinggal di daerah pesisir Kecamatan Kumai, Kabupaten Kotawaringin Barat, Kalimantan Tengah. Islam dianut oleh $98 \%$ penduduk Kumai, sedangkan sisanya, 2\%, tersebar pada agama-agama lain dan dianut oleh bukan penduduk asli. Meskipun demikian, tidak berarti Islam dijalankan dengan murni melainkan bercampur dengan budaya lokal yang kemudian menyatu sehingga sulit membedakan mana yang agama dan mana yang tradisi. Percampuran ini misalnya terlihat dari upacara nyanggar ${ }^{1}$ dan babarasih banua $^{2}$ yang

\footnotetext{
${ }^{1}$ Nyanggar adalah pemberian sesaji kepada makhluk halus yang menghuni sungai-sungai yang “dikeramatkan." Makhluk-mahkluk halus ini berupa seekor naga, tapah, buaya putih, dan pedatuan.

${ }^{2}$ Babarasih banua adalah upacara membersihkan banua (kota) dengan melakukan prosesi-prosesi adat. Melalui upacara ini diharapkan masyarakat penghuni banua ini akan hidup aman, damai, sejahtera, makmur, dan dijauhkan dari berbagai macam malapetaka yang merusak. Kerusuhan etnik yang pernah terjadi
} 
dilaksanakan setiap tahun di Kumai. Upacara adat ini semula adalah milik orang-orang Dayak, namun kemudian diadopsi oleh Bubuhan Kumai dengan beberapa penyesuaian dengan ajaran Islam yang mereka anut (Fadli, 2006).

Terbentuknya Bubuhan Kumai berdasarkan pada kesamaan agama yang mereka anut (Islam) dan asal-usul nenek moyang. Dari segi kesamaan agama, ada sebuah ungkapan yang menjadi kebanggaan dan identitas sejati mereka, "Urang Kumai pasti Muslim." Meskipun demikian, pernyataan tersebut tidak berarti bahwa Islam dilaksanakan dengan murni. Islam dalam realitas sosio-kultural Bubuhan Kumai telah bercampur dengan tradisitradisi lokal yang telah ada sebelumnya.

\section{Kepercayaan kepada Tuhan}

Dalam suatu sistem kepercayaan, orang membayangkan wujud dari dunia yang gaib, termasuk wujud dewa-dewa (theogoni), makhluk-makhluk halus, kekuatan sakti, keadaan ruh-ruh manusia yang telah meninggal, maupun wujud dari bumi dan alam semesta, yang dipelajari dalam ilmu kosmogoni dan kosmologi. Dalam agama-agama besar seperti Islam, Hindu, Budha, Katolik, Kristen, dan Yahudi, adakalanya sifat-sifat Tuhan tertera dalam kitab-kitab suci agama-agama tersebut, dan dengan demikian sifat-sifat Tuhan tersebut diserap pula ke dalam sistem kepercayaan dari agama-agama yang bersangkutan. Sistem kepercayaan itu ada yang berupa konsepsi mengenai paham-paham yang terbentuk dalam pikiran para individu penganut suatu agama, tetapi terdapat juga dalam konsepsi-konsepsi dan paham-paham yang dibakukan di dalam dongeng-dongeng dan aturan-aturan.

di Kumai dan Pangkalan Bun (Kotawaringin Barat) dipercaya karena mengabaikan upacara nyanggar dan babarasih banua ini. 
Dongeng-dongeng dan aturan-aturan ini biasanya merupakan kesusasteraan suci yang dianggap keramat (Koentjaraningrat, 2005: 203-204).

Dalam Islam sistem kepercayaan tersebut diformulasikan dalam Rukun Iman, sebagai akidah umat Islam, yang terdiri atas enam rukun, yakni beriman kepada Allah, beriman kepada para malaikat Allah, beriman kepada kitab-kitab Allah, beriman kepada rasul-rasul Allah, beriman kepada hari kebangkitan dan pembalasan yakni hari akhirat, atau kiamat, dan qada' dan qadar (takdir). Nilai-nilai yang terpancar dari Rukun Iman dipegangi dan dijadikan acuan tindakan, yang selanjutnya, lewat keyakinan-keyakinan itu, bangunan keagamaan atau syariah, yaitu aturan-aturan perihal tindakan yang harus dijalankan bagi setiap pemeluk dijabarkan dalam Rukun Islam (arkan al-islam), yang kemudian diformulasi, diberlakukan, dan dibakukan, sehingga orang beragama, secara sosial ditandai dan diukur dari keterpautan dengan aturan-aturan itu, dan bagaimana aturan-aturan itu dijalankan. Dengan kata lain, keislaman seseorang diukur dari kualitas pengetahuan dan praktik tindakan keagamaan yang bermuara kepada prinsip-prinsip akidah dan syariah tersebut.

Bagi Bubuhan Kumai Allah merupakan bagian yang sangat penting dalam kehidupan mereka, dan pengenalan tentang Allah harus dipahami dengan benar kemudian mewariskannya kepada generasi selanjutnya. Salah satu metode yang digunakan untuk mengenalkan dan sekaligus menanamkan makna Tuhan dalam kehidupan adalah melantunkan kalimah thayyibah (la ilaha Ilallah Muhammadurrasulullah) ketika menidurkan anak-anak mereka, di antaranya melalui lagu "Mengguringkan Anak" (Menidurkan Anak), sebagai berikut. 
"La ilaha Illallah Muhammadurrasulullah. Ayun diayun anak kusayang. Guringlah guring, anak kusayang. Ayahkam begawi gasan makan ikam. Ayahkam begawi gasan makan ikam. La ilaha Illallah Muhammadurrasulullah, anak kusayang. Ingatlah anakku, kalimah ini. Iniam gasan pingkutan ikam. Janganlah ikam lupa sampai matikam. La ilaha Illallah Muhammadurrasulullah. Ayun tam ayun. Guringam guringam."

"La ilaha Illallah Muhammadurrasulullah. Ayun diayun anak kusayang. Tidurlah tidur anak kusayang. Ayahmu bekerja untuk makanmu. Ayahmu bekerja untuk makanmu. La ilaha Illallah Muhammadurrasulullah. Ayun diayun anak kusayang. Ingatlah anakku, kalimah ini. Inilah pakai peganganmu. Janganlah kamu lupa sampai matimu. La ilaha Illallah Muhammadurrasulullah. Ayun diayun. Tidurlah tidur."

Lagu "Mengguringkan Anak" di atas menekankan 2 (dua) hal sebagai berikut. Pertama, mengenai seorang ayah yang pergi bekerja bertujuan untuk mencari nafkah keluarga yang disimbolisasikan dengan 'ayahkam begawi gasan makan ikam': ungkapan ini menegaskan tugas dan peran seorang laki-laki dalam kehidupan orang-orang Kumai, yakni bertanggung jawab terhadap keluarga. Kedua, lagu itu mengingatkan tentang pentingnya berpegang teguh pada la ilaha Illallah Muhammadurrasulullah, sebagai kalimat peneguhan ketauhidan seorang Muslim dan sekaligus pengakuan adanya Allah, Dzat yang harus disembah, Dzat yang menciptakan langit dan bumi dan Dzat yang memenuhi semua kebutuhan hidup manusia; sedangkan Muhammad adalah utusan Allah yang membimbing manusia ke jalan Allah. Untuk itu, la ilaha Illallah Muhammadurrasulullah harus dipegang kuat-kuat hingga mati.

Selain melantunkan lagu di atas, di kalangan Bubuhan Kumai ditemukan pula syairsyair monologis yang berisi pesan-pesan religius di dalamnya. Bait-bait monologis yang paling terkenal adalah Dddzikir Kekanakan; ${ }^{3}$ disebut Dzikir Kekanakan karena dzikir ini

\footnotetext{
${ }^{3}$ Bait-bait ini ada yang berupa oral dan tulisan. Penulis berterima kasih kepada Bapak Asran yang berkenan meminjamkan teks tertulis Ddzikir Kekanakan dan membacakannya di depan penulis dan menjelaskan makna-makna yang terkandung di dalamnya pada tanggal 16-07-2008.
} 
memang diperuntukkan bagi anak-anak sebagai media menanamkan nilai-nilai tauhid. Dalam bait-bait monologis itu, seorang ibu memerankan dirinya sebagai 2 (dua) peran, yakni ibu dan anak. Saat sang anak bertanya, si ibu akan mengubah suaranya seperti suara anak kecil, dan saat menjawab pertanyaan si ibu mengubah suaranya menjadi suara seorang ibu. Bunyi dzikir tersebut adalah sebagai berikut.

La ilaha Illallah

La ilaha Illallah

La ilaha Illallah

La ilaha Illallah

La ilaha Illallah

La ilaha Illallah

La ilaha Illallah

La ilaha Illallah

La ilaha Illallah

La ilaha Illallah

La ilaha Illallah

La ilaha Illallah

La ilaha Illallah

La ilaha Illallah

La ilaha Illallah

La ilaha Illallah

La ilaha Illallah

La ilaha Illallah

La ilaha Illallah

La ilaha Illallah

La ilaha Illallah

Muhammadurrasulullah

La ilaha Illallah

La ilaha Illallah

La ilaha Illallah

La ilaha Illallah

La ilaha Illallah

La ilaha Illallah

La ilaha Illallah berbatangkan apalah ibu?

berbatangkan sajaratul-

muntaha.

berakarkan apalah ibu?

berakarkan ayat Qulhuwallah.

berdahankan apalah ibu?

berdahankan ayat Fatihah

berdaunkan apalah ibu?

berdaunkan shalawatullah.

berpucukan apalah ibu?

berpucukan syahadah kalimah.

Di manakah bantalku ibu?

inilah bantal Siti Fatimah.

di manakah gegulingku ibu?

inilah geguling Siti Hawa.

buah apalah itu ibu?

itulah buah sadan tuani.

Di manakah jambanku ibu?

inilah jamban Rasulullah.

Di manakah kesandaranku ibu?

di damdampan Rasulullah.

La ilaha Illallah

Muhammadurrasulullah

berpohonkan apakah ibu?

berpohonkan sajaratul-muntaha.

berakarkan apakah ibu?

berakarkan surat al-Ikhlas.

berdahankan apakah ibu?

berdahankan surat al-Fatihah.

berdaunkah apakah ibu? 
La ilaha Illallah

La ilaha Illallah

La ilaha Illallah

La ilaha Illallah

La ilaha Illallah

La ilaha Illallah

La ilaha Illallah

La ilaha Illallah

La ilaha Illallah

La ilaha Illallah

La ilaha Illallah

La ilaha Illallah

La ilaha Illallah

La ilaha Illallah

Muhammadurrasulullah berdaunkan salawatullah ${ }^{4}$

berpucukkan apakah ibu?

berpucukan dua kalimah syahadat

di manakah bantalku ibu?

bantalmu Siti Fatimah

di manakah gegulingku ibu?

inilah geguling Siti Hawa

buah apakah ini ibu? ${ }^{5}$

ini adalah buah sumber kehidupan

di manakah titianku ibu?

inilah titian Rasulullah

di manakah tempat tidurku ibu?

di dipan Rasulullah.

La ilaha Illallah

Muhammadurrasulullah

Mencermati bait-bait dalam dzikir di atas, kandungannya terbagi dua pesan pokok, yakni tentang pedoman hidup dan hasil dari memegangi pedoman tersebut. Adapun rinciannya adalah sebagai berikut.

\section{Bagian I: Pedoman Hidup}

La ilaha Illallah

La ilaha Illallah

La ilaha Illallah

La ilaha Illallah

La ilaha Illallah

La ilaha Illallah

La ilaha Illallah

La ilaha Illallah

La ilaha Illallah

La ilaha Illallah berbatangkan apalah ibu?

berbatangkan syajaratul-muntaha.

berakarkan apalah ibu?

berakarkan ayat Qulhuwallah.

berdahankan apalah ibu?

berdahankan ayat Fatihah

berdaunkan apalah ibu?

berdaunkan shalawatullah.

berpucukan apalah ibu?

berpucukan syahadah kalimah.

${ }^{4}$ Maksudnya: salawat Nabi.

${ }^{5} \mathrm{Si}$ anak menunjuk pada buah payudara sang ibu. 
Dari bait-bait di atas, Syajaratul-Muntaha adalah simbolisasi dari pedoman hidup yang harus dipegang teguh. Pohon tersebut mempunyai akar, dahan atau cabang, daun, dan pucuk yang kokoh. Akar yang kokoh itu adalah Qulhuwallah, maksudnya surah al-Ikhlas; dahannya atau cabangnya adalah ayat Fatihah (surah al-Fatihah); daunnya adalah shalawatullah, maksudnya salawat; pucuknya atau bagian ujung daun adalah syahadah kalimah, maksudnya dua kalimat syahadat.

Pedoman ketiga yang terkandung dalam Syajaratul-Muntaha adalah membaca shalawat kepada Nabi Muhammad saw; dan yang terakhir adalah memegang teguh dua kalimat syahadat, dan kalimat inilah yang dapat mengantarkan manusia selamat di dunia dan di akhirat.

Apabila semua yang ada dalam pohon Syajaratul-Muntaha di atas sudah dipahami, dihayati, dan diamalkan, imbalannya adalah surga. Gambaran surga dalam Dzikir Kekanakan diuraikan sebagai berikut.

\section{Bagian II: Buahnya adalah Surga}

$\begin{array}{lc}\text { La ilaha Illallah } & \text { di manakah bantalku ibu? } \\ \text { La ilaha Illallah } & \text { inilah bantal Siti Fatimah. } \\ \text { La ilaha Illallah } & \text { di manakah gegulingku ibu? } \\ \text { La ilaha Illallah } & \text { inilah geguling Siti Hawa. } \\ \text { La ilaha Illallah } & \text { buah apalah itu ibu? } \\ \text { La ilaha Illallah } & \text { itulah buah sadan tuani. } \\ & \\ \text { La ilaha Illallah } & \text { di manakah jambanku ibu? } \\ \text { La ilaha Illallah } & \text { inilah jamban Rasulullah. } \\ \text { La ilaha Illallah } & \text { di mana kesandaranku ibu? } \\ \text { La ilaha Illallah } & \text { di damdampan Rasulullah. }\end{array}$

Menurut bait-bait di atas, mereka yang masuk surga akan merasakan segala nikmat yang ada di dalamnya. Di sana mereka akan tidur berbantalkan bantal sebagaimana bantal 
yang dipakai Siti Fatimah, puteri kesayangan Nabi Muhammad; memakai guling sebagaimana guling yang dipakai Siti Hawa; menikmati segala jenis buah-buahan; berjambankan jamban Rasulullah, maksudnya di surga mereka tidak akan pernah buang air besar atau air kecil; serta tidur beralaskan kasur Rasulullah. Surga yang dicitrakan dalam Dzikir Kekanakan mungkin hanya bagian kecil yang bisa dibayangkan oleh Bubuhan Kumai. Sementara itu, al-Qur'an telah memberikan gambaran-gambaran indah surga dalam beberapa ayatnya, antara lain sebagai berikut.

"Sesungguhnya penghuni surga pada hari itu bersenang-senang dalam kesibukan mereka. Mereka dan istri-istri mereka berada dalam tempat yang teduh, bertelekan di atas dipan-dipan. Di surga itu mereka memperoleh buah-buahan dan memperoleh apa yang mereka minta. (Kepada mereka dikatakan): "Salam," sebagai ucapan selamat dari Tuhan Yang Maha Penyayang" (QS. Ya Sin/36: 55-58). Dan sampaikanlah berita gembira kepada mereka yang beriman dan berbuat baik, bahwa bagi mereka disediakan surga-surga yang mengalir sungai-sungai di dalamnya. Setiap mereka diberi rezeki buah-buahan dalam surga-surga itu, mereka mengatakan: "Inilah yang pernah diberikan kepada kami dahulu." Mereka diberi buah-buahan yang serupa dan untuk mereka di dalamnya ada istri-istri yang suci dan mereka kekal di dalamnya (QS. al-Baqarah/2: 25). Mereka itulah (orang-orang yang) bagi mereka surga Adn, mengalir sungai-sungai di bawahnya; dalam surga itu mereka dihiasi dengan gelang emas dan mereka memakai pakaian hijau dari sutera halus dan sutera tebal, sedang mereka duduk sambil bersandar di atas dipan-dipan yang indah. Itulah pahala yang sebaik-baiknya, dan tempat istirahat yang indah" (QS. al-Kahfi/18: 31).

Pedoman hidup yang disimbolisasikan dengan Syajaratul-Muntaha di atas menunjukkan bahwa dalam alam pemikiran Bubuhan Kumai, untuk mencapai hidup yang bahagia atau surga, maka pedoman tersebut harus dijalankan dengan baik dan benar. Cara pandang seperti ini berpengaruh terhadap perilaku sehari-hari para penganutnya, yakni agama mempengaruhi sikap-sikap praktis manusia terhadap berbagai aktivitas kehidupan sehari-hari, dan pedoman tersebut dapat memberikan jawaban terhadap masalah makna kehidupan. Secara struktural-fungsional agama melayani kebutuhan-kebutuhan manusia 
untuk mencari kebenaran dan mengatasi serta menetralkan berbagai hal buruk dalam kehidupannya. Semua agama menyajikan formula-formula tersebut, yang pada hakikatnya bersifat mendasar dan umum berkenaan dengan eksistensi dan perjalanan hidup manusia, yang masuk akal dan rasional sesuai dengan keyakinan keagamaannya, mendalam serta penuh dengan muatan-muatan emosi dan perasaan yang manusiawi (Geertz, 1966: 1-46). Karena hal-hal buruk yang dihadapi oleh manusia selalu membayangi kehidupannya, dan karena agama dapat menyajikan penjelasan-penjelasan yang masuk akal dan cara-cara yang mendasar dan umum untuk menetralkan atau mengatasi bayangan-bayangan buruk tersebut, maka agama tetap lestari dalam kehidupan manusia, sepanjang zaman selama manusia ada (Suparlan, 1993: X-XI).

\section{Kepercayaan kepada Makhluk Halus}

Kepercayaan kepada makhluk gaib atau makhluk halus memperlihatkan bahwa orang-orang Kumai senada dengan pemahaman muslim lainnya, kecuali ada sedikit pemahaman mengenai malaikat yang dipercaya dapat menjelma manusia biasa dalam kondisi-kondisi khusus. Selain itu, terdapat pula istilah-istilah makhluk halus khas lokal Bubuhan Kumai, yakni kepercayaan pada makhluk-makhluk halus di luar yang disebutkan dalam al-Qur'an atau hadis; mereka mempercayai adanya makhluk-makhluk halus lain yang mempunyai hubungan "kerabat" dengan manusia, karena dipercaya sama-sama dilahirkan. Untuk itu mereka harus tetap memberikan penghormatan berupa perlakuan khusus kepada makhluk-makhluk tersebut agar memperlancar kegiatan mereka. Keyakinan seperti ini dianggap sebuah kebenaran dan tidak mungkin ditinggalkan. Kejadian-kejadian di beberapa tempat dianggap sebagai bukti eksistensi dari makhluk-makhluk tersebut. 


\section{1. "Makhluk-makhluk" Lokal}

Orang Kumai mempunyai istilah-istilah sendiri dalam menyebut makhluk-makhluk halus (gaib), seperti gegana, pedatuan, gambaran, urang gaib, dan hantu laut. Tiap-tiap makhluk ini mempunyai karakteristik sendiri-sendiri. Adapun makhluk-makhluk halus yang keberadaannya dipercayai hingga kini adalah datu buaya dan urang gaib.

Selama penelitian lapangan, penulis menyaksikan peristiwa yang sangat langka untuk ukuran penulis, yakni orang-orang berkerumun menyaksikan seekor buaya raksasa sepanjang 13 (tiga belas) meter dengan berat 1 (satu) ton atau $1000 \mathrm{~kg}$. Menurut mereka, buaya ini telah menelan seorang bapak berusia 45 (empat puluh lima) tahun ketika orang tersebut sedang merakit kayu-kayu gelondongan di Sungai Sepingit. Pada tanggal 2 Januari 2009, buaya tersebut berhasil ditangkap oleh seorang pawang buaya. Peristiwa tertangkapnya buaya ini menyebar ke mana-mana, sehingga orang berduyun-duyun menyaksikan buaya tersebut. Dari peristiwa tertangkapnya buaya ini timbul berbagai macam cerita mengenai hal-ihwal buaya yang cenderung berbau mitos ketimbang realitas ilmiah.

Menurut mereka, buaya mempunyai kampung seperti manusia, dan manusia mempunyai kembaran dengan buaya. Pada peristiwa-peristiwa tertentu, seperti perkawinan, khitanan, dan lain-lain, buaya ini meminta bebarian atau sesaji. Jika tidak dituruti ia akan mengganggu dengan merasuk salah seorang anggota keluarga yang seketurunan dengan kembaran buaya tersebut. Dari kepercayaan ini muncul istilah datu buaya, yang merupakan sebutan untuk makhluk halus yang mempunyai kekuatan luar biasa dan pada waktu tertentu akan menampakkan diri. Penamapakan ini dipercaya sebagai 'mealamat' (pertanda) bahwa 
akan terjadi kejadian-kejadian yang kurang baik bagi masyarakat Kumai. Menurut beberapa informan yang ditanyai tentang peristiwa kerusuhan etnis di Kumai pada tahun 2001 yang lalu, bahwa para pencari daun nipah melihat seekor buaya besar timbul di tengah-tengah sungai Sekonyer. Beberapa bulan kemudian terjadi kerusuhan etnis. Menurut Pak Ijun, Sungai Sekonyer dijaga oleh gegana berupa buaya putih, yang muncul pada waktu-waktu tertentu dan kemunculannya ini adalah pertanda akan terjadi peristiwa besar di Kumai.

"Sungai Sekonyer di huni oleh gana, yang bernama Datu Buaya. Datu ini mendiami sebuah tempat di dalam sungai ini yang disebut puaka buaya. Kalau dia muncul di sungai Sekonyer sesak dengan badannya dan muncul di sore hari yang ditandai dengan cuaca hujan panas. Tapi tidak mengganggu. Menurut cerita-cerita tetuha zaman dulu, jika buaya ini menampakkan diri berarti memberi pertanda tidak baik bagi masyarakat, akan terjadi sebuah peristiwa. Kerusuhan yang pernah terjadi di Kumai beberapa tahun lalu adalah bukti dari kemunculan Datu tersebut" (Wawancara, 13-07-2008).

Informan lain, Pak Barmawi, menuturkan bahwa di Kumai Hulu ada orang yang menggaduh buaya putih. Keluarga ini harus memberi makan buaya tersebut setiap tahunnya. Kalau tidak diberi makan, ia akan mengganggu keamanan Kumai. Buaya ini adalah gambaran (kembaran) dari manusia. Menurut cerita-cerita leluhur, buaya ini dilahirkan bersamaan dengan seorang anak manusia. Karena ia berupa hewan, maka ia pun diletakkan di Sungai Nyirih, sedangkan saudaranya dibesarkan layaknya bayi manusia. Bayi manusia ini setelah dewasa, biasanya mendatangi saudaranya di Sungai Nyirih dengan membawa makanan sesaji. Kebiasaan ini kemudian menjadi turun-temurun dan keturunan ini tidak bisa melepaskan tanggung jawabnya dalam memelihara dan berkomunikasi dengan buaya tersebut (Wawancara, 19-07-2008). 
Beberapa peristiwa yang berkaitan makhluk-mahkluk halus dituturkan secara lisan dan dipercaya sebagai faktual. Sungai Nyirih dipercaya ada penjaganya berupa makhluk halus. Orang memang banyak yang tidak percaya, tapi ada kejadian yang membuktikan keberadaan makhluk ini. Seorang pengusaha yang membangun sebuah pelabuhan di sana telah membuktikannya. Orang-orang kampung sekitar telah menyarankannya agar mengadakan selamatan, tetapi pengusaha tersebut tidak percaya, dan pelabuhan pun dibangun di sana. Bahan-bahannya dari kayu ulin yang sangat kokoh, sehingga tidak mungkin roboh atau rusak. Namun yang terjadi, pelabuhan tersebut hilang tanpa meninggalkan bekas apa pun. Menurut kesaksian orang yang kebetulan memancing di dekat lokasi tersebut, pelabuhan itu bergerak ke laut dan akhirnya tenggelam.

Pelabuhan yang hilang tersebut menimbulkan berbagai versi cerita. Ada yang mengatakan, kayu-kayu pelabuhan tersebut mengenai bagian belakang ikan besar. Versi lain mengatakan bangunan tersebut mengganggu buaya putih yang merupakan penunggu sungai tersebut, sehingga ia marah dan membuang bahan-bahan pelabuhan tersebut ke laut. Kejadian yang sama terulang lagi waktu pengusaha lain membangun pelabuhan di sebelahnya, dan pelabuhan tersebut juga hilang.

Selain cerita-cerita di atas, orang Kumai juga meyakini keberadaan makhlukmakhluk halus yang berperan penting dalam menjaga Kumai. Kepercayaan ini dapat dilihat dari penuturan Pak Anang (45 th). Menurutnya, Kumai ada penjaganya. Sungai-sungai di Kumai ada penjaganya. Benua ${ }^{6}$ ini dijaga oleh empat makhluk halus, yang tersebar di empat penjuru Kumai: utara-selatan-timur-barat. Mereka inilah yang menjaga keamanan

\footnotetext{
${ }^{6}$ Benua: kota, dalam pengertian di sini berarti ‘Kecamatan Kumai,' obyek penelitian ini.
} 
masyarakat di sini. Karena itu, setiap tahun masyarakat harus mengadakan upacara nyanggar dan babarasih ${ }^{7}$ (membersikan) benua agar makhluk-makhluk tidak mehawur (mengganggu dan membuat kerusakan).

Pak Abdoellah Apuan, seorang guru, mengaku mempunyai gambaran Datu Buaya yang bernama Datu Bolang, dan makhluk halus yang disebut Datu Buaya itu memang ada.

"Saya sendiri mempunyai Datu Bolang. Kisahnya sebagai berikut: "Waktu almarhum kakekku, Haji Muhammad Yusuf lahir, beliau lahir kembar dengan bayi buaya. Bayi buayanya lahir pertama baru disusul beliau. (Buaya itu) lalu dipelihara di sungai. Ketika almarhum kakekku masih hidup, beliau inilah yang dengan setia merawat saudara kembarnya itu. Kalau beliau dan keluarga mau mengadakan upacara, seperti perkawinan, khitanan, dan lain-lain, (beliau) selalu mendatangi buaya ini dan memberitahukan maksud keluarga. Kalau saudara kembar buaya ini tidak diberitahu, maka ia akan mengganggu. Berdasarkan pengalaman saya, biasanya buaya ini merasuk kepada salah seorang keluarga yang masih satu garis keturunan dengan kakekku. Seseorang yang dirasuki buaya ini akan kesarungan (kesurupan) dan berperilaku seperti buaya. Tubuh yang dimasuki buaya tersebut kekuatannya berlipat ganda seperti kekuatan buaya, sehingga kalau dipegang beberapa orang saja tidak kuat. Anehnya, orang yang kesarungan tadi meskipun dibacakan ayat-ayat al-Qur'an tidak mempan. Suatu kesempatan, ada keluarga saya yang sedang beselamatan (kenduri) untuk sebuah acara, tapi tidak memberitahu buaya ini. Ia marah dengan menyakiti salah seorang keluarga saya. "Kalau sudah ada bukti-buktinya apakah kita tetap tidak mempercayainya? Kalau saya pribadi tetap mempercayai adanya karena ia adalah gambaran bukan makhluk asing yang menghampiri keluarga saya. Meskipun begitu ada juga keluarga saya yang agamanya kuat tidak mempercayai ini. Tapi daripada bertengkar tidak karuan, lebih baik kami selenggarakan saja memberinya makan tanpa sepengetahuannya."

Di lain kesempatan, Pak Abdoellah Apuan juga menuturkan pengalaman yang pernah dialaminya.

Waktu aku kecil, ketika mau menutup jendela kulihat ada seekor ular. Kuambil kayu, kupukulkan ke ular tadi dan ia pun mati, kubuang di tumpukan pohon bambu. Tidak berapa lama kemudian, ibuku sakit. Matanya terbelalak menatap langit-langit rumah. Habis magrib, habis sembahyang magrib beliau terdiam. Kupanggil keluargaku, lalu ibuku tadi berkata dan menunjuk ke arahku: 'Aku ini Datu Bolang. Dia ini yang memukul anak cucu kami, ular. Ularnya mati dan dibuang di tumpukan pohon bambu.' Aku mengakui, betul apa yang dikatakan beliau. Lalu ia mau menempel pada ibuku. Tapi keluarga yang lain tidak mau dengan alasan ibuku sudah melaksanakan sembahyang sehingga tidak layak memelihara makhluk seperti itu. Akhirnya, Bang Durahman yang menyanggupi. Jadi beliau itulah yang memeliharanya sampai ke anak cucunya. Jadi kalau ada acara keluarga,

\footnotetext{
${ }^{7}$ Upacara ini mirip upacara bersih desa di Jawa.
} 
misalnya perkawinan, khitanan, diambilkan air di laut lalu dicipratkan kepada yang mau menikah. Tidak akan terjadi apa-apa. Cuma itu saja permintaannya" (Wawancara, 19-072008).

Menurut Pak Abdoellah Apuan, buaya ini dapat memberikan bantuan kepada keluarga yang memeliharanya.

Ketika salah seorang keluarga saya yang sedang berlayar tenggelam gara-gara menabrak batu senggora di laut; waktu itu hampir saja ditenggelamkan kalau tidak memandang anak cucunya. Rupanya, pemilik kapal tersebut tidak percaya dan tidak peduli dengan buaya ini sehingga ia marah.

\section{2. Urang Gaib: Sungai Kalap}

Menurut penuturan Bubuhan Kumai, Sungai Kalap ${ }^{8}$ dihuni oleh urang gaib. Salah satu cerita yang paling populer dan dipercaya sebagai kenyataan adalah adanya seorang dealer sepeda motor dari Jakarta yang ingin menagih sisa pembayaran yang tinggal separohnya. Cerita ini diperoleh dari Pak Abdullah Apoean.

"Ada seseorang yang bercerita langsung kepadaku, namanya Ijum. Menurutnya ceritanya, ada orang dari Jakarta datang ke Kumai dan mencari Kampung Kalap. Kata orang Jakarta tersebut, ada orang Kalap membeli sepeda motor, namun baru dibayari separohnya dan saya disuruh datang ke Kalap mengambil kekurangannya. Ijum tadi keheran-heranan, karena sepengetahuannya, Kalap itu adalah hutan belantara. Tapi, tetap saja orang Jakarta tadi tidak percaya dengan keterangan Ijum. Lalu Ijum pun mengajak orang tadi dengan sepedamotornya. Sesampainya di Kalap, orang Jakarta tersebut keheranheranan dan hampir tidak percaya bahwa hutan yang dilihat dengan mata kepalanya adalah Kalap. Menurut bayangannya waktu di Jakarta Kalap itu sebuah kelurahan atau kecamatan, namun nyatanya hanyalah himpunan pohon-pohon. Di tengah-tengah keheranannya itu muncul sebuah amplop persis di dekat kakinya. Ia pungut amplop itu dan membukanya: "Utang segera kami lunasi." Sesudah membaca isi surat tersebut, orang Jakarta tadi mengajak Ijum pulang ke hotel di Pangkalan Bun. Belum lama ia duduk, ada telepon dari bosnya di Jakarta yang memberitahukan bahwa utang orang Kalap sudah dilunasi dan ia

\footnotetext{
${ }^{8}$ Sungai Kalap terletak sebelah selatan Kumai Hulu. Untuk sampai ke tempat ini ditempuh dengan klotok/speedboat atau jalan darat (motor, sepeda motor).
} 
segera harus segera kembali ke Jakarta" (Wawancara dengan Pak Abdulla Apoean, 19-072008). ${ }^{9}$

Cerita-cerita lain menyebutkan, orang-orang yang memancing di Sungai Kalap sering menyaksikan adanya pertunjukan musik di sini. Pak Hanafiyah (36) pernah mengalami sendiri ketika ia sedang memancing di sungai tersebut. Ia mendengar pertunjukan musik ndangdut yang menyanyikan lagu-lagu Rhoma Irama. Ia terheran-heran dengan kejadian itu, karena ia tahu persis ketika berlabuh untuk memancing di situ yang tampak hanyalah hamparan pohon-pohon bakau, tetapi tiba-tiba ada pertunjukan musik.

Catatan lapangan ini memperlihatkan, di sekitar Sungai Kalap terdapat sebuah pancuran air, udara di sini agak dingin dan bernuansa mistis. Di sudut-sudut pancuran terdapat ancak (tempat sesajen) yang berisi wadai apam (roti khas Kumai), rokok selinting (sebatang rokok berasal dari tembakau dan dibungkus dengan daun kelapa muda), dan sebiji telur ayam kampung matang. Sesajen tersebut diberikan kepada makhluk gaib penghuni Sungai Kalap.

\section{3. Bersahabat dengan Makhluk Halus}

Pak Barmawi menuturkan, bahwa di Kumai ada orang yang bersahabat dengan makhluk halus, yang dikenal dengan nama hantu laut. Disebut hantu laut, karena makhluk ini hidupnya di laut dan mereka mempunyai seorang pemimpin, Raja Hantu Laut. Pernah seorang pengusaha China yang akan menurunkan perahu dagangnya dari daratan ke lautan mengalami kesulitan. Perahu tidak beranjak dari tempatnya meski telah ditarik dengan 3 (tiga) buah kapal takbot (tugboat). Bahkan tali-tali penarik yang berukuran sebesar lengan orang dewasa putus. Akhirnya diputuskanlah untuk memanggil Kyai Tabri, seorang yang dianggap bersahabat dengan makhluk halus (bahasa lokal: sahabat hantu laut). Ia memberikan sesaji berupa nasi kuning, telur ayam kampung, rokok kelinting, dan asap menyan, kemudian beliau menepuk bagian buritan perahu. Luar biasa! Perahu tersebut bergerak dengan sendirinya tanpa perlu ditarik dengan kapal takbot.

${ }^{9}$ Cerita ini saya coba tanyakan juga kepada beberapa informan lain, termasuk Pak Ijum yang menjadi saksi hidup pada saat itu. Ia membenarkan kisah tersebut dan ia sendiri yang mengantarkan dealer dari Jakarta itu ke Sungai Kalap. 
Kejadian serupa pada tahun 2007, ketika K. M. Dharma Kencana II mau meninggalkan Pelabuhan Panglima Utar (Kumai) pada jam 19.00. Meski nakhoda kapal telah mengerahkan tenaga mesin maksimal yang ditandai dengan asap mengepul-ngepul hitam, namun kapal tetap tidak bisa bergerak. Setelah berlalu selama kurang lebih 2 (dua) jam, maka ada petugas pelabuhan yang memberikan sesaji berupa nasi kuning, sebiji telur ayam kampung, dan sebatang rokok kelinting; lima menit kemudian kapal tersebut seperti didorong ke laut, dan akhirnya K. M. Dharma Kencana II dapat berlayar ke Pulau Jawa dengan selamat.

Masih menurut Pak Barmawi, orang yang bersahabat dengan Raja Hantu Laut akan memberikan manfaat bagi tuannya: [1] Raja Hantu Laut ini akan memberitahu tuannya kalau kematian sudah tiba saatnya; [2] membantu dalam pelayaran, sehingga gelombang sebesar apa pun tidak akan mampu menenggelamkan kapal; dan [3] membantu dalam menangkap ikan. Orang yang bersahabat dengan hantu laut dapat dimintai bantuannya dalam menangkap ikan. Orang lain tidak dapat tangkapan ikan, orang yang bersahabat dengan hantu laut sebentar saja memasang pukat (jaring) atau memancing akan dapat ikan dalam jumlah banyak. Kalau kita melihat ada buih di laut jangan ditegur, karena itu adalah Raja Hantu Laut sedang menampakkan dirinya. Kalau berani menegur serta merta orang yang menegur itu terkena sakit perut dan penyakit lainnya.

Kepercayaan Bubuhan Kumai terhadap jenis-jenis makhluk halus atau gaib, selain yang disebutkan dalam al-Qur'an dan Hadis Nabi, yang bertugas menjaga “dunia” Kumai dan dapat bersahabat dengan mereka, merepresentasikan adanya pengaruh-pengaruh lama ke dalam keislaman mereka saat ini. Meskipun demikian, Bubuhan Kumai meyakini bahwa 
makhluk-makhluk tersebut adalah ciptaan Tuhan dan berada di bawah kendali-Nya - bukan makhluk-makhluk dalam fenomena alam yang merupakan entitas tersendiri atau memiliki kekuatannya sendiri. Selain itu, bagi Bubuhan Kumai, adanya makhluk gaib dianggap sebagai konsekuensi logis dari adanya makhluk fisik. Tidak ada makhluk yang merupakan entitas yang berdiri sendiri atau memiliki kekuatan sendiri. Manusia sekalipun, tanpa kekuasaan Tuhan, tidak dapat mengendalikan sesama makhluk atau kekuatan semacam itu.

Implikasi dari kepercayaan di atas, Bubuhan Kumai setidaknya memiliki dua keyakinan, yaitu, pertama, bahwa posisi makhluk gaib tidak sebanding dengan kekuasaan Tuhan, dan kedua, tidak ada karakter ketuhanan lain atau hak bagi satupun makhluk halus untuk diperlakukan seperti Tuhan. Dalam kenyataannya, keyakinan akan adanya makhluk halus bukan monopoli tradisi tertentu seperti animisme, melainkan juga satu ciri banyak tradisi, termasuk Islam dan Kristen. Jika referensi ajaran Islam diperlukan di sini, ada sebuah ayat al-Qur'an (QS. al-Baqarah/2: 2-3), misalnya, yang menyebutkan bahwa orangorang beriman adalah mereka yang percaya, antara lain, kepada yang gaib, dan ini secara pasti termasuk makhluk halus. Bertolak dari sini, kepercayaan Bubuhan Kumai akan makhluk halus tetaplah dalam koridor ajaran al-Qur'an dan Hadis. Yang membedakan adalah dikenalnya beberapa istilah lokal yang seolah-olah di luar keterangan dua sumber utama Islam tersebut. Fenomena seperti ini ditemukan juga dalam tradisi-tradisi lokal lain, seperti di Jawa dan daerah-daerah lain di Kalimantan yang mengenal beberapa istilah makhluk-makhluk halus dengan peran dan fungsinya masing-masing.

Melihat peran dan fungsi makhluk halus lokal Bubuhan Kumai seperti diuraikan di atas, tampak sekali bahwa makhluk halus bukan hanya merupakan mitos semata-mata. 
Makhluk-makhluk tersebut diakui keberadaannya dan hidup berdampingan dengan masyarakat lokal yang bertugas untuk melindungi dan menjaga Kumai. Kepercayaan ini diwariskan secara turun-temurun dan memuat nilai-nilai budi pekerti yang dilestarikan oleh pemiliknya.

Kepercayaan di atas kemungkinan merupakan sisa-sisa dari kepercayaan lama yang masih terpelihara dalam memori Bubuhan Kumai dan ketika agama Islam dianut tidak serta merta agama yang diamanatkan kepada Nabi Muhammad saw ini menghapuskan kepercayaan lama tersebut. Merujuk penelitian yang dilakukan Radam (2001) terhadap religi Orang Bukit, disebutkan bahwa Orang Bukit membagi diri manusia ke dalam tiga oknum, yakni Raja Umbayang, Limbagan (Diri Nyata) dan Dangsanak Ampat (Saudara Empat). Ketiga oknum diri manusia ini adalah satu kesatuan yang tak terpisahkan: ke mana pun Limbagan, ke sanalah Raja Umbayang dan Dangsanak Ampat. Namun demikian, Limbagan lebih banyak dipengaruhi dan ditentukan gerak-geriknya oleh kedua oknum tersebut. Raja Umbayang, sebagai saudara yang tertua yang tinggal di dasar tiang langit dipandang berperan mengarahkan kehidupan Limbagan; dia merupakan sumber teladan buruk dan baik, dengan kata lain, sumber kelakuan moral dan etik. Raja Umbayang diidentifikasikan sebagai tinggal di langit, mempunyai sifat Bapang dan mempunyai kemampuan menaklukkan, kelaki-lakian dan perkasa.

Dangsanak Ampat, yang merupakan saudara Limbagan lainnya tinggal di hamparan bumi paling bawah, berperan memeliharanya. Dia merupakan sumber aktivitas dan kasih sayang. Dia berkemampuan memanaskan dan mendinginkan Limbagan. Dia memberi keseimbangan. Sementara itu, Raja Umbayang dipandang sebagai sumber inspirasi dan 
Dangsanak Ampat sebagai sumber aktivitas dan kreativitas. Keduanya disebut Dangsanak Lima (Radam, 2001: 186-188).

Keyakinan akan adanya guardian spirit tersebut telah dicatat oleh G. P. Murdock (1961) pada berbagai masyarakat bersahaja. Di kalangan masyarakat Aranda di Australia Tengah roh pelindung itu disebut churinga; di masyarakat Samoa Pasifik dikenal dengan nama genii, yakni kelompok roh pelindung rumah tangga. Pada masyarakat Indian Inka di Peru, roh pelindung itu digolongkan ke dalam huauqui yang berarti saudara, yakni roh pelindung perorangan, dan pacarina, yakni roh pelindung sekalian orang; dan pada masyarakat Dahomei di Afrika Barat roh pelindung itu adalah roh nenek moyang yang karena keinginan agar namanya abadi diangkat menjadi djoto atau roh pelindung bagi setiap orang sepanjang hidup yang bersangkutan. Pada masyarakat Trunyan roh pelindung itu disebut Nyama Pat, yang berfungsi melindungi jasad manusia dan memberikan tambahan tenaga hidup (Danandjaja, 1980: 328-329).

Dalam penafsiran ilmu antropologi tentang mitos dan mitologi, terkait kenisbian makna sesuai dengan kelompok masyarakat yang mendukungnya. Sebagai penyederhanaan keterangan tentang kosmos dan sejarah, mitos memiliki fungsi memasok masyarakat dengan kesadaran makna dan tujuan hidup yang amat penting. Oleh karena itu, dapat dikatakan bahwa manusia tidak dapat bertahan hidup tanpa sistem mitologi dan bentukbentuk tertentu (Madjid, 1995: 214-219). Dengan demikian, masyarakat lokal sering kali tidak mempersoalkan apakah mitos-mitos itu memang benar-benar ada atau tidak. Bagi mereka, mitos berarti suatu cerita yang benar, dan cerita ini menjadi milik mereka yang paling berharga (Daeng, 2000: 16). 
Menurut Dhavamony (1995: 150), mitos dalam kaitannya dengan agama, menjadi penting bukan semata-mata memuat kejadian-kejadian ajaib atau peristiwa-peristiwa mengenai makhluk-makhluk adikodrati, melainkan karena mitos tersebut memiliki fungsi eksistensial bagi manusia. Mitos merupakan kisah yang diceritakan untuk menetapkan kepercayaan tertentu, berperan sebagai peristiwa pemula dalam suatu upacara atau ritus, atau sebagai model tetap dari perilaku moral ataupun relijius. Karenanya, mitologi atau tradisi suci dari suatu masyarakat adalah kumpulan cerita yang terjalin dalam kebudayaan mereka, yang menyuarakan keyakinan mereka, menentukan ritus mereka, yang berlaku sebagai peta peraturan sosial maupun sebagai model tetap dari tingkah laku moral mereka. Setiap mitos mengandung isi literer karena selalu berbentuk narasi. Akan tetapi, narasi ini bukan sekedar dongeng yang menghibur ataupun pernyataan yang diberikan kepada penganut agama. Mitos adalah cerita sejati mengenai kejadian-kejadian yang bisa dirasa telah turut membentuk dunia dan hakikat tindakan moral, serta menentukan hubungan ritual antara manusia dengan penciptanya, atau dengan kuasa-kuasa yang ada (Malinowski, 1954).

\section{Simpulan}

Dalam kehidupan dan sistem kepercayaan Bubuhan Kumai Allah sebagai Tuhan umat Islam merupakan bagian yang sangat penting. Pengenalan tentang dan keimanan terhadap Allah harus dipahami dengan benar kemudian diwariskan kepada generasi selanjutnya. Salah satu metode untuk mengenalkan dan sekaligus menanamkan makna Tuhan dalam kehidupan adalah melantunkan kalimah thayyibah (la ilaha Illallaah Muhammadurrasulullah) ketika menidurkan anak-anak mereka, di antaranya melalui lagu 
"Mengguringkan Anak" (Menidurkan Anak). Kepercayaan kepada makhluk gaib atau makhluk halus dalam masyarakat Bubuhan Kumai menunjukkan pemahaman khas lokal terhadap berbagai jenis makhluk halus, di luar yang disebutkan dalam al-Qur'an dan hadis. Mereka mempercayai adanya makhluk-makhluk halus lain yang mempunyai hubungan "persaudaraan" dengan manusia, karena dipercaya sama-sama dilahirkan. Untuk itu mereka memberikan perlakuan khusus kepada makhluk-makhluk tersebut agar memperlancar kegiatan dan hajat mereka. Keyakinan yang mengandung unsur-unsur ajaran lama sebelum Islam seperti ini dianggap kebenaran dan sulit ditinggalkan. Kejadian-kejadian gaib di tempat-tempat tertentu dianggap sebagai bukti hadirnya berbagai macam makhluk halus.

Pelanggaran terhadap kepercayaan demikian dapat berakibat tidak baik bagi pelanggarnya, seperti dalam kasus pengusaha yang mencoba membangun pelabuhan di Sungai Nyirih yang gagal total. Pelabuhan yang dibangun dengan bahan-bahan yang kokoh tersebut hanyut dibawa oleh makhluk halus yang menghuni lokasi tersebut. Kejadian ini diyakini betul oleh masyarakat Kumai, sehingga tidak ada yang berani membangun pelabuhan di sungai tersebut, kecuali mendapat dukungan dari makhluk halus yang menjaganya.

\section{Daftar Pustaka}

Daeng, Hans J. 2000. Manusia, Kebudayaan dan Lingkungan: Tinjauan Antropologis. Yogyakarta: Pustaka Pelajar.

Danandjaja, J. 1980. Kebudayaan Petani Desa Trunyan di Bali: Lukisan Analitis yang Menghubungkan Praktik Pengasuhan Anak Orang Trunyam dengan Latar Belakang Etnografisnya. Jakarta: Pustaka Jaya.

Daud, Alfani. 1997. Islam dan Masyarakat Banjar: Deskripsi dan Analisa Kebudayaan Banjar. Jakarta: P. T. Raja Grafindo Persada. 
Dhavamony, Mariasusasi. 1995. Fenomenologi Agama. Penerjemah A. Sudiarja, dkk. Yogyakarta: Kanisius.

Fadli, Ibrahim. 2006. "Pelaksanaan Upacara Adat Nyanggar dan Babarasih Banua." Makalah Diskusi Tahunan Menyambut Pelaksanaan Upacara Adat Nyanggar dan Babarasih Banua.

Geertz, Clifford. 1966. The Religion of Java. Chicago dan London: The University of Chicago Press.

Hermansyah. 2002. Magi Ulu Kapuas: Kajian atas Ilmu Masyarakat Melayu Embau. Tesis S2 Program Pascasarjana IAIN Walisongo Semarang. . 2010. Ilmu Gaib di Kalimantan Barat. Jakarta: KPG-École Française d'Extrême-Orient-KITLV dan STAIN Pontianak.

Koentjaraningrat. 2006. Pengantar Antropologi: Pokok-pokok Etnografi Jilid II. Jakarta: Rineka Cipta.

Madjid, Nurcholish. 1992. Islam: Doktrin dan Peradaban. Jakarta: Yayasan Wakaf Paramadina.

Malinowski, Bronislaw. 1954. Magic, Science and Religion. Garden City, New York: Anchor Books.

Murdock, G.P. 1961. Our Primitive Contemporaries. New York: The Macmillan Company.

Radam, Noerid Haloei. 2001. Religi Orang Bukit: Suatu Lukisan Struktur dan Fungsi dalam Kehidupan Sosial-Ekonomi. Yogyakarta: Semesta.

Suparlan, Parsudi. 1993. "Kata Pengantar," dalam Roland Robertson (Ed.), Agama dalam Analisa dan Interpretasi Sosiologis (penerjemah Achmad Fedyani Saifuddin). Jakarta: Raja Grafindo Persada. 